\title{
SEISMIC PERFORMANCE EVALUATION OF PFS METHOD BY SOIL-WATER COUPLED FINITE DEFORMATION ANALYSIS
}

\author{
*Kentaro Nakai ${ }^{1}$, Kakuta Fujiwara ${ }^{2}$ and Nanase Ogawa ${ }^{3}$ \\ ${ }^{1}$ Faculty of Engineering, Nagoya University, Japan; ${ }^{2}$ Faculty of Engineering, Tokai University, Japan; Giken \\ Ltd., Japan
}

*Corresponding Author, Received: 29 Nov. 2021, Revised: 15 Dec. 2021, Accepted: 09 Jan. 2022

\begin{abstract}
The PFS method (Partially Floating Sheet pile method) has been frequently used as a countermeasure to reduce settlement during embankment construction due to the edge cutting effect near the embankment toe. However, the anti-seismic effect has not yet been fully discussed. Therefore, to expand the applicability of the PFS method, seismic response analyses for river embankments on sand - clay alternating soft ground was conducted using soil-water coupled finite deformation analysis. As a result, it was shown that the embankment damage (settlement of the embankment crown and horizontal displacement of the embankment toe) caused by the earthquake decreased in the order of no countermeasure, floating sheet pile method, PFS method, and end bearing sheet pile method, which indicates that the anti-seismic effect of the PFS method was confirmed. Moreover, the PFS method was considered to be more effective in suppressing lateral flow, especially near the ground surface, compared with the floating sheet pile method.
\end{abstract}

Keywords: PFS method, Seismic response analysis, Lateral displacement, Sand - clay alternating soft ground

\section{INTRODUCTION}

Steel sheet piles have been used for temporary construction to suppress lateral deformation of the ground and ensure stability. However, at present, it is also used as a permanent structure not only to prevent slip failure but also to reinforce embankments and suppress lateral flow and settlement in the soft ground under embankment construction. As for the settlement countermeasure method using steel sheet piles, the end bearing sheet pile method has been used so far, in which all the piles are embedded into the supporting layer. However, if the soft ground is thick, the pile length becomes very long and causes cost problems. In addition, the floating sheet pile method, which does not allow the piles to penetrate to the supporting layer, is economically effective and can be expected to have a certain effect on settlement countermeasures, but it also has the disadvantage of settlement of the pile itself. Based on these problems, the PFS method (Partially Floating Sheet pile method) is shown in Figure. 1 has been developed.

The PFS method has many achievements in river embankments on the soft ground of the Kumamoto Plain. In the 2016 Kumamoto earthquake, there is a report that the PFS method, which was implemented as a countermeasure against settlement and lateral displacement, also suppressed the deformation during the earthquake [1]. However, the aseismic effect has not yet been fully discussed for the PFS method. Therefore, to expand the applicability of the PFS method, seismic response analyses of river embankment on sand clay alternating ground were conducted.

In this paper, a numerical investigation on the aseismic effect of the PFS method was conducted, as well as the effect of settlement and lateral displacement at the time of static loading due to embankment construction. The analysis code employed in this study was the soil-water coupled finite deformation analysis GEOASIA [2], which incorporates an elastoplastic constitutive model, namely the SYS Cam-clay model [3], that allows a description of the behavior of soils ranging from sand through intermediate soils to clay within the same theoretical framework [4]. This analysis code can be applied to both ground deformation and failure and can be used to analyze co-seismic behavior over a time range of a few seconds to a few minutes and post-seismic behavior, in which case the time range is from a few years to a few centuries.

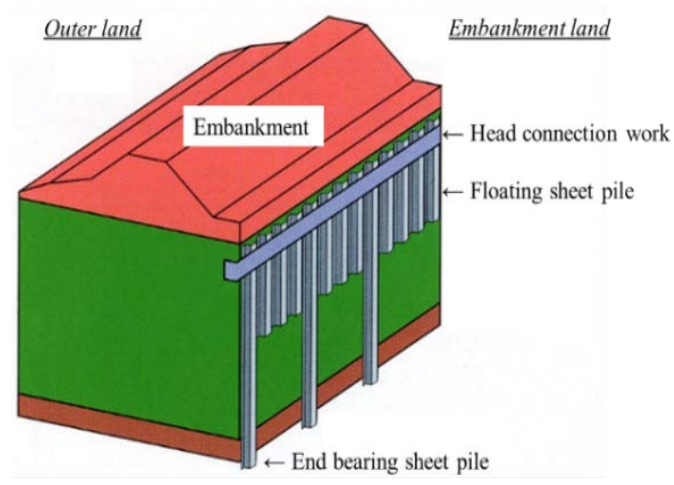

Fig. 1 Schematic figure of PFS method 


\section{ANALYSIS CONDITION}

Figure 2 shows the finite element mesh used in this analysis. Target ground was soft sand-clay layer ground near the estuary of the Kikuchi river in Kumamoto plain. The ground was assumed to be initially horizontally layered, with an alternate layer of sand and clay. The hydraulic boundaries for the subsurface were designated as drained boundaries, and the bottom end and the two lateral faces were designated to be under undrained conditions. Periodic boundaries were realized by tying two nodes with the same height between both lateral ends.

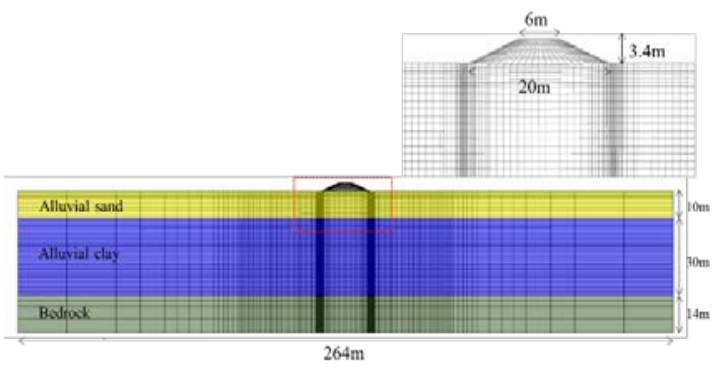

Fig.2 Finite element mesh used in the analysis

Table 1 shows the elastoplastic parameters (material constants and initial conditions) of the soils used in this analysis. These parameters were all determined based on the results of laboratory testing using undisturbed samples obtained from insitu boring surveys. The elastoplastic parameters were determined by replicating the results of these mechanical behaviors using the SYS Cam-Clay Model. Figures 3 and 4 show some examples of the reproduction results. The parameters were identified by reproducing the shear behavior to the compression behavior with a single set of material constants. For detail, please see reference [5].

Table 1 Elasto-plastic parameters of soils

\begin{tabular}{lcccc}
\hline & Emb & Sand & Clay & Bedrock \\
\hline Elasto-plastic parameters & & & & \\
Critical state index M & 1.60 & 1.60 & 1.65 & 1.80 \\
NCL intercept N & 1.70 & 2.28 & 1.90 & 2.00 \\
Compression index $\tilde{\lambda}$ & 0.05 & 0.165 & 0.243 & 0.05 \\
Swelling index $\tilde{\kappa}$ & 0.005 & 0.025 & 0.020 & 0.005 \\
Poisson's ratio $v$ & 0.30 & 0.20 & 0.40 & 0.10 \\
Evolution parameters & & & & \\
Degradation index of structure $a$ & 1.00 & 1.00 & 0.60 & 0.01 \\
Ratio of $-D_{v}{ }^{p}$ to $\left\|D_{s}{ }^{p}\right\| c_{s}$ & 1.00 & 1.00 & 0.07 & 1.00 \\
Degradation index of OC $m$ & 5.00 & 3.00 & 10.0 & 20.0 \\
Rotational hardening index $b r$ & 0.00 & 0.00 & 0.00 & 0.00 \\
Limit of rotational hardening $m_{b}$ & 0.00 & 0.00 & 0.0 & 0.00 \\
Initial conditions & & & & \\
Specific volume v & - & - & - & - \\
Stress ratio $\eta_{0}$ & 0.545 & 0.545 & 0.545 & 0.545 \\
Degree of structure $1 / R^{*}{ }_{0}$ & 1.0 & 1.05 & 20.0 & 1.00 \\
Degree of overconsolidation $1 / R_{0}$ & 200.0 & 30.0 & 1.80 & 500.0 \\
Degree of anisotropy $\varsigma_{0}$ & 0.00 & 0.00 & 0.00 & 0.00 \\
Soil particle density $\rho_{s}(\mathrm{~g} / \mathrm{cm} 3)$ & 2.65 & 2.65 & 2.65 & 2.65 \\
Mass permeability index $k(\mathrm{~cm} / \mathrm{s})$ & $1.0 \times 10^{-5}$ & $1.0 \times 10^{-4}$ & $1.0 \times 10^{-6}$ & $1.0 \times 10^{-7}$ \\
\hline & & & &
\end{tabular}
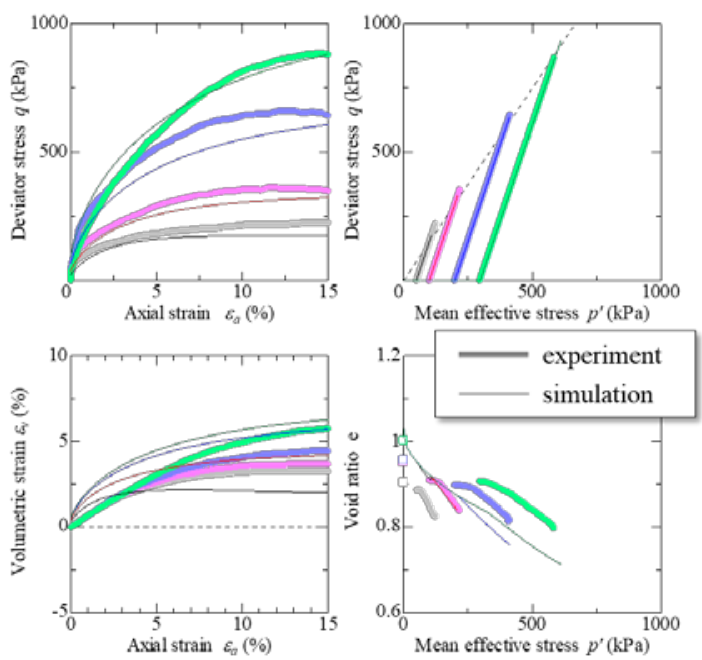

Fig. 3 Undrained shear behavior of clay

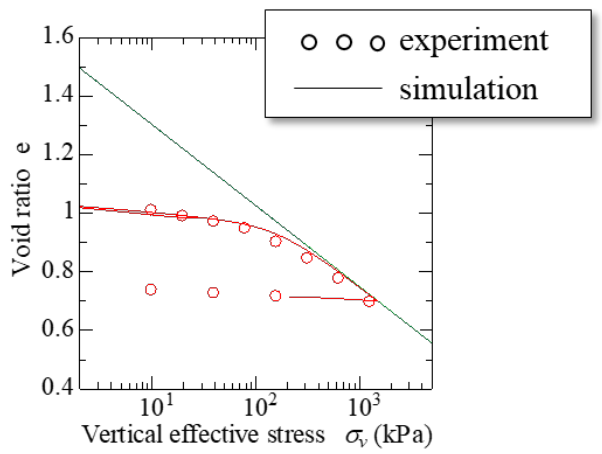

Fig. 4 One-dimensional compression behavior of clay

Table 2 shows the elastic parameters of sheet piles used in this analysis. The two-dimensional modeling of the PFS method was considered as follows [6-8]. Although the sheet pile shows a complicated shape, it is considered as a mixture of the sheet pile and the surrounding ground and modeled as a one-phase elastic body so that the rigidity and weight per unit depth are equal. In addition, in the case of the PFS method under plane strain conditions, sheet piles and ground exist discretely in the same plane. Therefore, we considered the space between the end-bearing sheet piles as one unit and assumed average the rigidity within the unit. It was modeled as a two-phase elastic body and the hydraulic conductivity is assumed to be equal to the ground.

Table 2 Elastic parameters for steel sheet pile

\begin{tabular}{lccc}
\hline & $\begin{array}{c}\text { Actual } \\
\text { sheet pile }\end{array}$ & $\begin{array}{c}\text { Sheet pile } \\
\text { 1-phase mat. }\end{array}$ & $\begin{array}{c}\text { Sheet pile } \\
\text { 2-phase mat. }\end{array}$ \\
\hline Density $\rho(\mathrm{g} / \mathrm{cm} 3)$ & 7.80 & 1.80 & 1.80 \\
Poisson's ratio $v$ & 0.3 & 0.3 & 0.3 \\
Young's modulus $E(\mathrm{GPa})$ & 200 & 43.15 & 7.2 \\
Mass permeability index $k(\mathrm{~cm} / \mathrm{s})$ & - & - & $1.0 \times 10^{-6}$ \\
\hline
\end{tabular}


Numerical analyses were carried out in the following steps.

1) A steel sheet pile was modeled by replacing the soil with a linear elastic material.

2) Embankments $3.4 \mathrm{~m}$ in height with slope gradients of 2:1 were constructed on the initial ground by adding finite element meshes.

3) The seismic waveform was input in the horizontal direction equally on all nodes of the bottom face of the ground. The seismic motion was the assumed Nankai trough earthquake prepared by the Cabinet Office. As you can see from Figure 5, in addition to large acceleration, seismic motion contains many long-period components and has a long duration.

4) After the earthquake, consolidation has proceeded until the deformation converged.
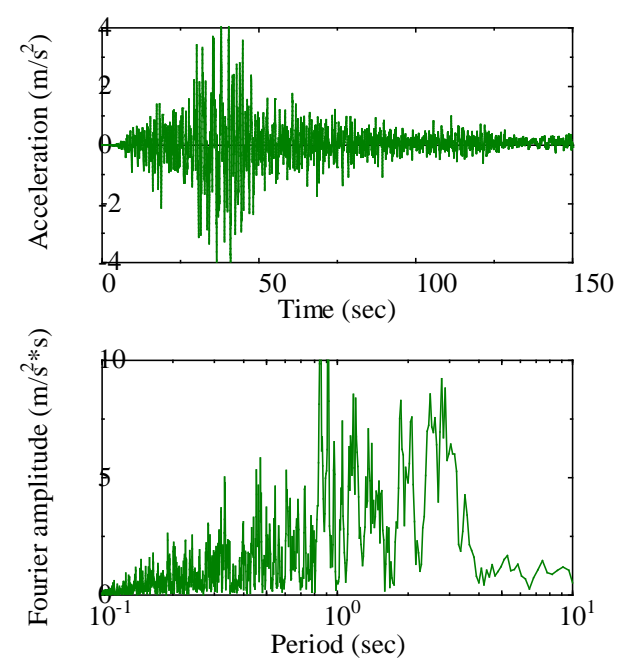

Fig. 5 Input seismic motion (expected Nankai trough earthquake by Cabinet Office)

\section{ANALYSIS CASES}

Figure 6 shows the distribution of settlements in the depth direction during the embankment construction. The ground is the case of no countermeasures, and the measurement point of the settlement was at the embankment toe. According to the PFS method manual [9], the embedment depth of the floating sheet pile in the PFS method is calculated as the neutral point of the settlement distribution map. Therefore, the embedment depth of the floating sheet pile was determined as $20 \mathrm{~m}$ in this research.

Figure 7 shows five analysis cases. The left side of the figure (assuming the outer land side of the embankment) is assumed to have end-bearing sheet piles in all cases. In addition to the (a) no countermeasure ground, (b) the end bearing sheet

pile method, and (c) the floating sheet pile method was assumed. Moreover, two types of PFS methods with different floating sheet pile lengths were assumed.

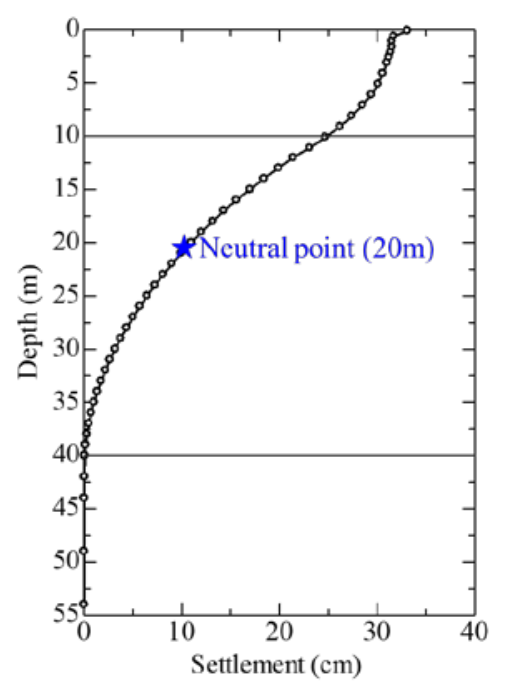

Fig. 6 Settlement distribution in the depth direction

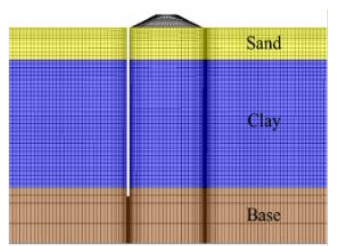

(a) No countermeasure

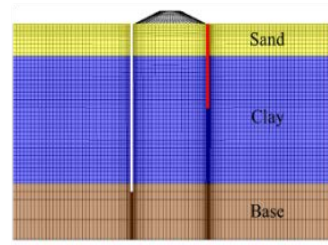

(c) Floating sheet pile: depth $20 \mathrm{~m}$

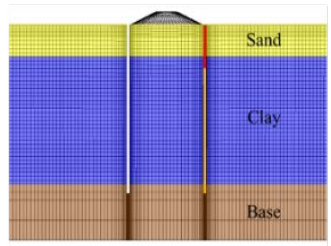

(e) PFS: depth $12 \mathrm{~m}$ with 5 floating pile

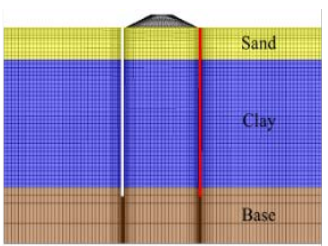

(b) End bearing sheet pile

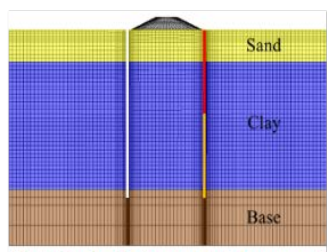

(d) PFS: depth $20 \mathrm{~m}$ with 5 floating pile

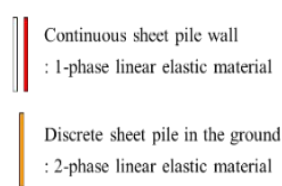

Fig. 7 Analysis cases (different countermeasures)

\section{LATERAL SUPPRESSION EFFECT DURING EMBANKMENT CONSTRUCTION}

Figures 8 and 9 show the settlement at the embankment crown and lateral displacement at the embankment toe caused by the embankment construction. 


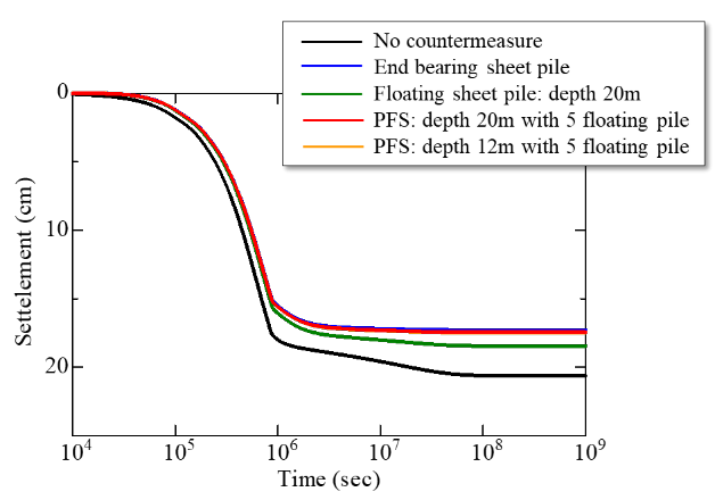

Fig. 8 Settlement at the embankment crown

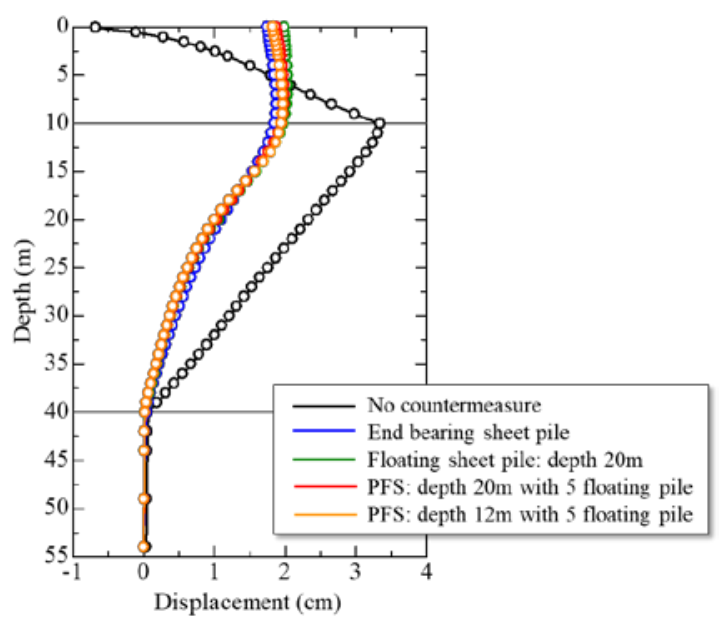

Fig. 9 Lateral displacement distributions to depth direction at the embankment toe

Compared to no countermeasures for both the settlement and the horizontal displacement, the amount of deformation can be suppressed in the order of the floating sheet pile method, the PFS method, and the end-bearing sheet pile method. This tendency is also consistent with the reference [10]. There is no significant difference in deformation depending on the type of countermeasure, but this is thought to be due to the large sand layer thickness of $10 \mathrm{~m}$. This is considered to be due to the dispersing effect of the embankment load by the thick sand layer.

\section{ANTI-SEISMIC EFFECT OF THE VARIOUS STEEL SHEET PILE METHODS}

Figure 10 shows the settlement at the embankment crown during and after the earthquake. The initial settlement is the displacement during the embankment construction shown in Fig. 8. Figure 11 shows lateral displacement distributions to depth direction at the embankment toe 300 seconds after the occurrence of an earthquake.

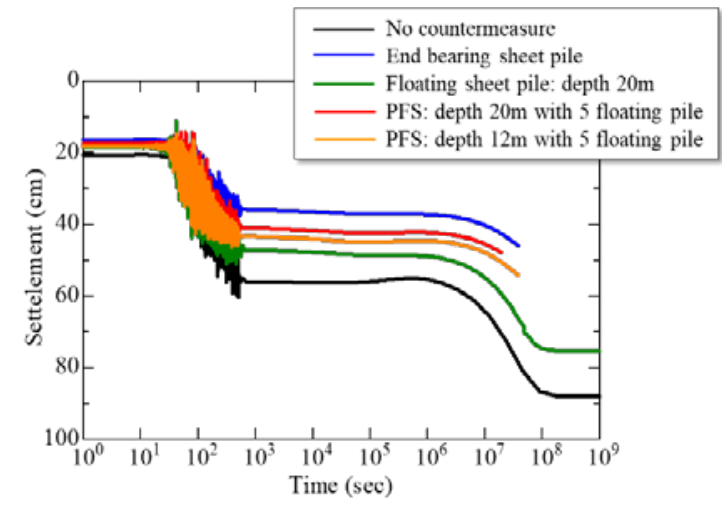

Fig. 10 Settlement during and after the earthquake at the embankment crown

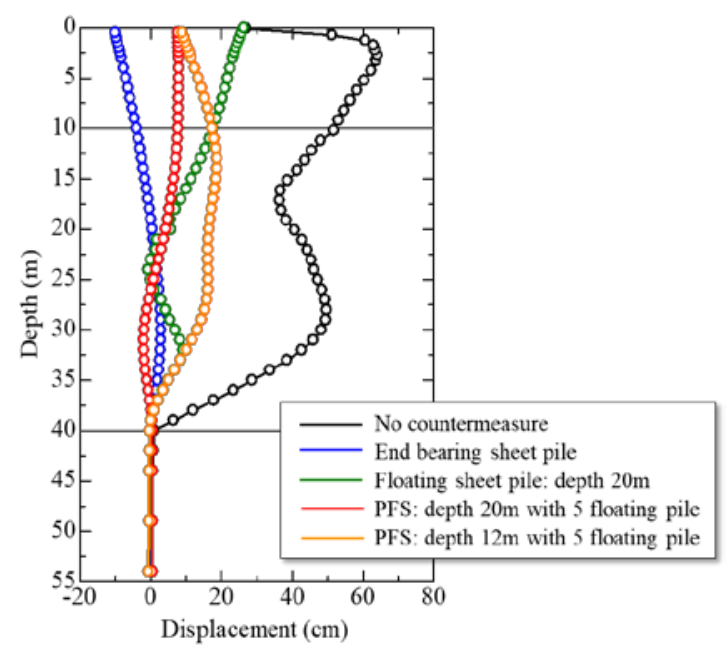

Fig. 11 Lateral displacement distributions to depth direction at the embankment toe 300 seconds after the occurrence of an earthquake

Unlike the static behavior during embankment loading, the dynamic deformation during an earthquake differs depending on the countermeasures. In the case of no countermeasures, the embankment will sink $90 \mathrm{~cm}$ and cause a lateral displacement of about $60 \mathrm{~cm}$ near the ground surface. However, in the case of the end-bearing sheet pile method, the amount of settlement will be reduced to about 2/3. Moreover, there is no lateral displacement at the embankment toe; it is pulled by the embankment settlement and causes a slight negative displacement. The floating sheet pile method and the PFS method are located between no countermeasures and end bearing sheet pile method. However, the floating sheet pile method has a larger amount of deformation and is close to no countermeasures. As can be seen from Figure 12 below, in the case of the floating sheet pile method, the shear strain is concentrated at the tip of the sheet pile, and it can be seen that the clay layer near the tip was disturbed. The PFS method has a smaller 


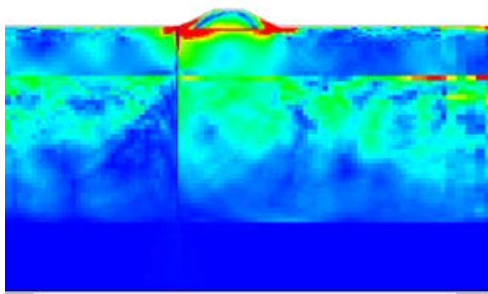

(a) No countermeasure

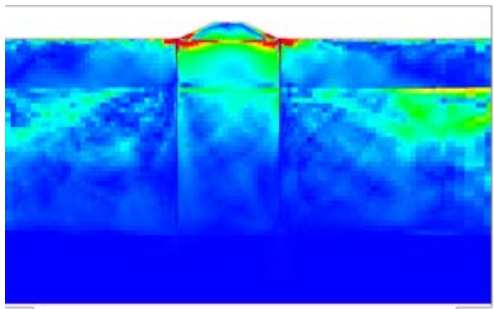

(d) PFS: depth $20 \mathrm{~m}$ with 5 floating pile

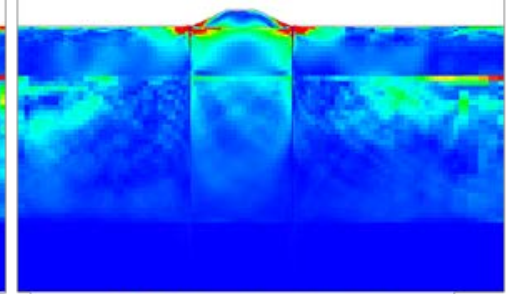

(b) End bearing sheet pile

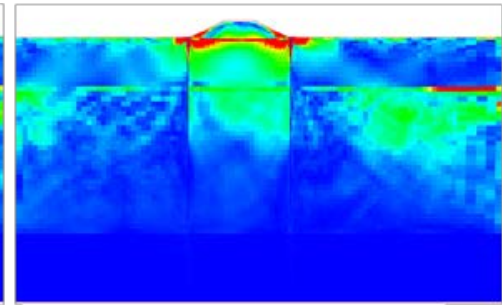

(e) PFS: depth $12 \mathrm{~m}$ with 5 floating pile

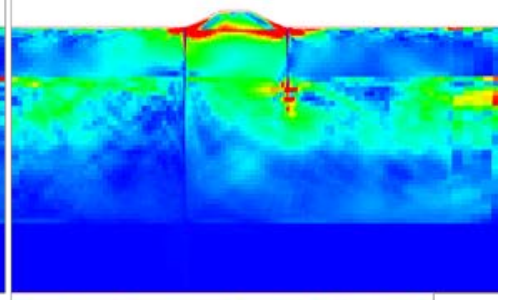

(c) Floating sheet pile: depth $20 \mathrm{~m}$

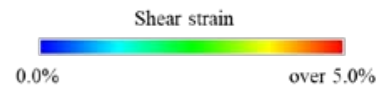

Fig. 12 Shear strain distributions 300 seconds after the occurrence of an earthquake

amount of deformation than the floating sheet pile method and is close to an end-bearing sheet pile method. In particular, the effect of suppressing lateral displacement near the ground surface is great It can be seen that when the depth of the floating sheet pile is shallow, lateral displacement (slipthrough that occurs between the end bearing sheet piles) occurs in the deep part of the ground. However, when the embedment depth of the floating pile is $20 \mathrm{~m}$, the amount of slip-through can be strongly suppressed.

Next, the influence area of seismic deformation was examined. Fig. 12 shows shear strain distributions 300 seconds after the occurrence of an earthquake. In the case of no countermeasures or the floating sheet pile method, it can be seen that the shear strain spreads in the embankment land region on the right side of the figure. In the case of the PFS method, although it is not as good as the endbearing sheet pile method, the shear strain growth to the embankment land was suppressed, and the deeper the depth of the floating sheet pile, the greater the effect.

Figure 13 shows the maximum bending moment acting on the sheet pile during embankment construction and earthquake. Comparing the bending moments acting on the sheet pile during embankment construction and during earthquakes, it can be seen that the bending moments during the earthquake are overwhelmingly larger than that of embankment construction. Since this research targeted a huge earthquake called the Nankai Trough earthquake, it means that there is a risk that a large moment will act during the earthquake and might exceed the yield and/or permissible values.

From the above discussions, the embankment deformation caused by the earthquake decreased in the order of no countermeasure $>>$ floating sheet pile method $>$ PFS method $>$ end bearing sheet pile method, and the aseismic effect of the PFS method could be confirmed. In addition, the PFS method is considered to be more effective in suppressing lateral flow, especially near the ground surface, than the floating sheet pile method. In the case of the floating sheet pile method, the sheet pile itself flows together with the ground because the ground at the tip of the sheet pile was disturbed.

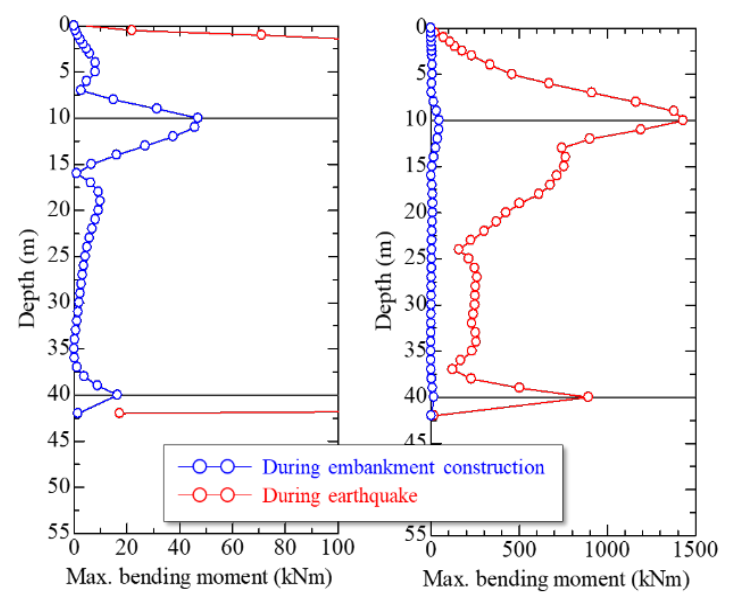

Fig. 13 Cross-section performance check of the sheet pile in case of PFS method with its floating pile $20 \mathrm{~m}$

\section{CONCLUSION}

In this paper, a numerical investigation on the aseismic effect of the PFS method was conducted using soil-water coupled finite deformation analysis. Although the PFS sheet pile has a complicated 
three-dimensional structure, a simple twodimensional plane strain model is derived by giving the average physical properties (equivalent rigidity and equivalent weight) of the steel sheet pile and the ground per unit depth. The following conclusions were obtained.

1) Embankment damage (settlement of the embankment crown and horizontal displacement of the embankment toe) caused by the earthquake decreased in the order of no countermeasure $>>$ floating sheet pile method $>$ PFS method $>$ end bearing sheet pile method, and the aseismic effect of the PFS method was confirmed.

2) PFS method was considered to be more effective in suppressing lateral flow, especially near the ground surface, than the floating sheet pile method. In the case of the floating sheet pile method, the sheet pile itself flows together with the ground because the ground at the tip of the sheet pile was disturbed.

Since this study was conducted under the condition that the sand layer thickness was relatively large. Therefore, it is necessary to investigate when the sand layer thickness was thinner, and when the soil layer conditions were different. In addition, since the seismic motion was very large as the Nankai trough earthquake, we should further work with different input seismic motion characteristics. Based on these additional studies, we would like to evaluate the aseismic performance of the PFS method and promote the expansion of the application of the PFS method.

\section{ACKNOWLEDGMENTS}

This research was supported by the International Press-in Association TC3 (Chair: Prof. Jun Otani). The authors express deep appreciation for the cooperation and useful discussion.

\section{REFERENCES}

[1] Kasama K., Yamamoto S., Ohno M., Mori H., Tsukamoto S., and Tanaka J., Seismic damage analysis on the river levees reinforced with steel sheet pile by the 2016 Kumamoto earthquake, Japanese Geotechnical Journal, Vol.15, No.2, 2020, pp395-404.

[2] Noda, T., Asaoka, A., and Nakano, M., Soilwater coupled finite deformation analysis based on a rate-type equation of motion incorporating the SYS Cam-clay model, Soils and Foundations, Vol. 48, No. 6, 2008, pp. 771-790.

[3] Asaoka, A., Noda, T., Yamada, E., Kaneda, K., and Nakano, M., An elastoplastic description of two distinct volume change mechanisms of soils, Soils, and Foundations, Vol. 42, No. 5, 2002, pp. 47-57.

[4] Nakano, M., Nakai, K., and Asaoka, A., A description of mechanical behavior of clay and sand based on evolutions of soil structure and over consolidation, ASCE Geotechnical Special Publication No.143, Geomechanics: Testing Modeling and Simulation, 2003, pp.136-153.

[5] Nakai, K., Noda, T., Taenaka, S., Ishihara, Y., and Ogawa, N., Seismic assessment of steel sheet pile reinforcement effect on river embankment constructed on soft clay ground, Proceedings of the First International Conference on Press-in Engineering, 2018, pp.221-226.

[6] Nakai, K., Noda, T., and Kato, K., Seismic assessment of river embankments reinforced by the sheet pile constructed on a low $\mathrm{N}$-value soft ground, Canadian Geotechnical Journal, Vol.54, No. 10, 2017, pp. 1375-1396.

[7] Fujiwara, K., Ogawa, N. and Nakai, K., 3-D numerical analysis for the partial floating sheet-pile method under liquefaction, Journal of JSCE, Vol. 9, No.1, 2021, pp.138-147.

[8] Ogawa, N., Fujiwara, K. and Nakai, K., Analytic considerations on two-dimensional modeling of partial floating sheet pile method, Proceedings of 11th International Conference on Geotechnique, Construction Materials and Environment, GEOMATE 2021.

[9] PFS method association, Technical note for the PFS method, 2005. in Japanese.

[10] Kasama, K., Fujiyama, H. and Otani, J., 3D fem analysis of partial floating steel sheet piling method on the two-layered ground, Proceedings of 2nd International Conference on Press-in Engineering (ICPE) 2021.

Copyright (C) Int. J. of GEOMATE All rights reserved, including making copies unless permission is obtained from the copyright proprietors. 